\title{
Goddag til historien
}

\author{
af Troels Fink
}

På Historisk Samfunds årsmøde i Broager den 26.maj 1966 blev jeg valgt til formand for foreningen. Det havde aldrig været min ambition at nå formandsposten, jeg befandt mig godt som menigt medlem af styrelsen siden 1956. Men Peter Kr.Iversen, der havde gjort en helt enestående indsats ved at reorganisere Historisk Samfund og ved at udvide dets opgavekreds, ville gerne aflastes efter $10 \mathrm{år} \mathrm{som} \mathrm{formand.} \mathrm{Jeg} \mathrm{lovede} \mathrm{at} \mathrm{fungere} \mathrm{som} \mathrm{midlertidig} \mathrm{formand} \mathrm{i}$ to år $\mathrm{i}$ håb om, at P.Kr. Iversen så igen ville overtage formandshvervet. Men han blev ramt af sygdom, og de to år blev til fem. I 1971 overtog han igen sin gamle post; min periode har været en parentes, men ikke desto mindre rig på begivenheder.

Når man gennemlæser de gamle årsberetninger, får man indtryk af en grøderig periode $\mathrm{i}$ foreningens historie. Det lykkedes at holde et medlemstal på mellem 2900 og 3000, der var god fremgang for Sønderjysk Månedsskrift takket være den dygtige redaktion med Inger Bjørn Svensson i spidsen. Dertil kom en rig bogproduktion, der fandt god afsætning. Man kan roligt sige, at den historiske interesse udfoldede sig så fuldtonende som nogensinde.

Denne tingenes tilstand står i grel modsæetning til den krise, faget historie i folkeskolen netop i disse år løb ind $\mathrm{i}$. I tiden fra dengang til 1984 fik folkeskolen fire forskellige vejledninger for faget historie. I en vejledning fra 1975 hedder det, at formålet med undervisningen er, at eleverne erhverver viden om tidligere tiders levevilkår, tankesæt og samfundsforhold, og at de får en oplevelse af sammenhængen mellem fortid og nutid og af de forandringer, der har fundet sted i menneskelige udfoldelsesmuligheder. Det kan lyde meget godt, men resultatet var, at historien blev opløst i sine bestanddele; der tales nok om sammenhæng mellem fortid og nutid, men udgangspunktet for denne sammenhæng er ganske vilkårligt; man ofrede kontinuiteten i den danske historie på modens alter. Det skal straks tilføjes, at man siden har erkendt fejlen. $\mathrm{Nu}$ vil man gøre eleverne fortrolige med den tradition, det danske samfund og kulturliv bygger på som forudsætning både for forandring og videreførelse. Tendensen har på samme måde svinget i gymnasieskolen.

Den skade, der er forvoldt i 1970'erne, er nok uoprettelig. En stor del af det stof, der hører til det danske dannelsesgrundlag, er forsvundet, og det er et spørgsmål, om det er nok at lade historien være en tradition. 


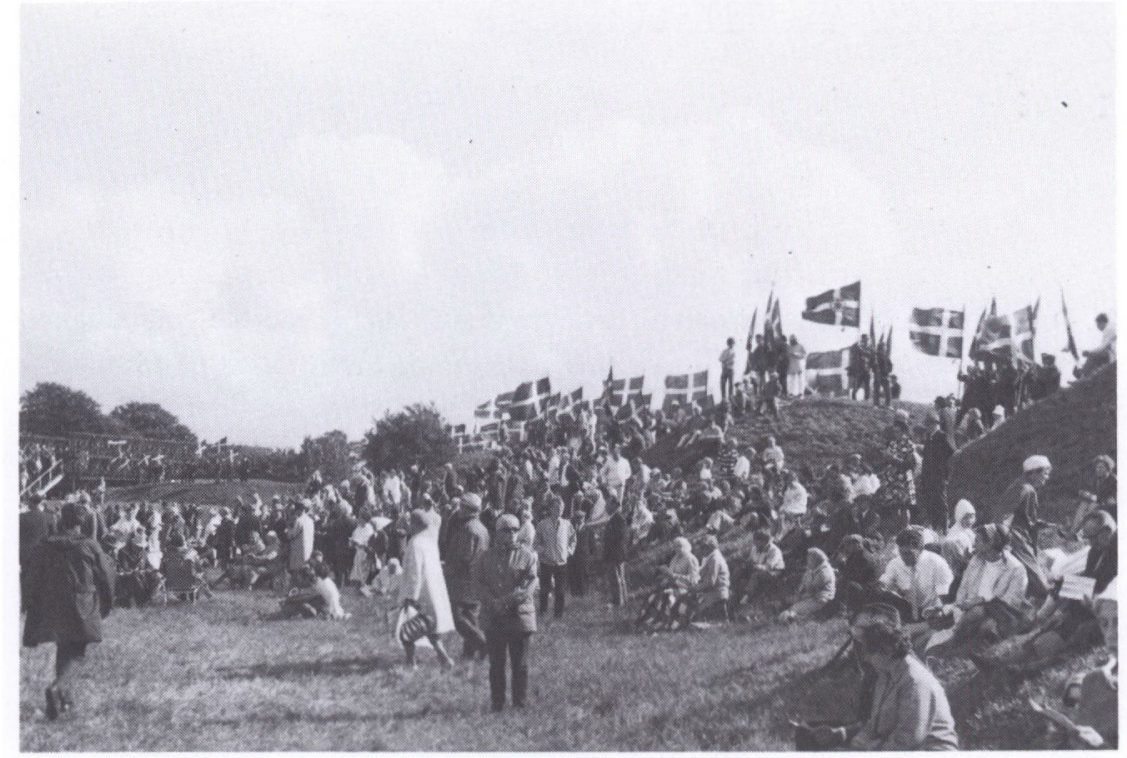

Den store 50 års mindefest for Genforeningen den 11 .juli 1970 blev en virkelig national og folkelig festdag. En stor deltagerskare med kongeparret og statsministeren $i$ spidsen overvarede festen, og lange rakker af Dannebrog fra landsdelens foreninger dannede ramme om arrangementet. Her ses et glimt fra festdagen optaget gennem rigsarkivar Johan Hvidtfeldts kamera. Historiske Samlinger, Aabenraa.

Den bølge af kritik mod den hævdvundne historieundervisning, som dengang skyllede ud over landet, kom i kølvandet på det såkaldte ungdomsoprør i 1968. Dette og dets følger blev tilsyneladende en parentes i samfundsudviklingen, men her i Sønderjylland fik det følger for forløbet af den store 50 års mindefest for Genforeningen den 11.juli 1970 på Dybbøl Banke.

Det var Historisk Samfund for Sønderjylland, der stod som arrangør. Foreningen har altid vedstået, at den er en dansk national organisation, så det var naturligt at tage opgaven op.

Forberedelserne begyndte straks, da jeg tiltrådte som formand. Det var den oprindelige idé bag denne fest, at de yngre slægtled, børn og børnebørn af genforeningsgenerationen, her skulle bringe de ældre en tak og hyldest for den indsats, de under store vanskeligheder havde gjort for at forberede Genforeningen $o g$ for at sammensmelte det sønderjyske område med det, vi kaldte »det gamle land«. Man kan vel nok sige, at børnene af genforeningsgenerationen forstod betydningen af det, der var sket i 1920; børnebørnene forstod det næppe; for dem var 1920 blevet fjern fortid. Det skulle vi måske have været opmærksomme på fra begyndelsen, om ikke straks, så i al fald fra 1968, da ungdomsoprøret tog sin begyndelse. 
Foruden de helt unge talere havde vi indbudt forfatteren Peter Seeberg til at yde et bidrag til festen, gerne i bunden form. Det ønskede digteriske bidrag fik vi ikke, men derimod en tale, hvor Peter Seeberg fandt det passende at sige farvel til historien. Han gjorde det med følgende begrundelse:

"Der er allerede sket for meget. Vi ønsker ingen historie mere. Vi beder om tid til at tænke os om, tid til at ændre, tid til at fortryde, « og han sluttede: "Måtte vore dage fortsætte i sommer og vinter, hændelsesløst og stille, foruroligede i vore huse, prisgivet tidens tilstrækkelighed.« Talen kan i sin helhed læses i »Sønderjylland 1970. Taler i jubilæumsåret«. Udg. af Historisk Samfund for Sønderjylland, 1971 s. 41-42.

Det var med stor overraskelse, jeg hørte disse ord, og ved nærmere overvejelse forekom de mig at være nonsens. Uanset hvor meget der er sket, vil

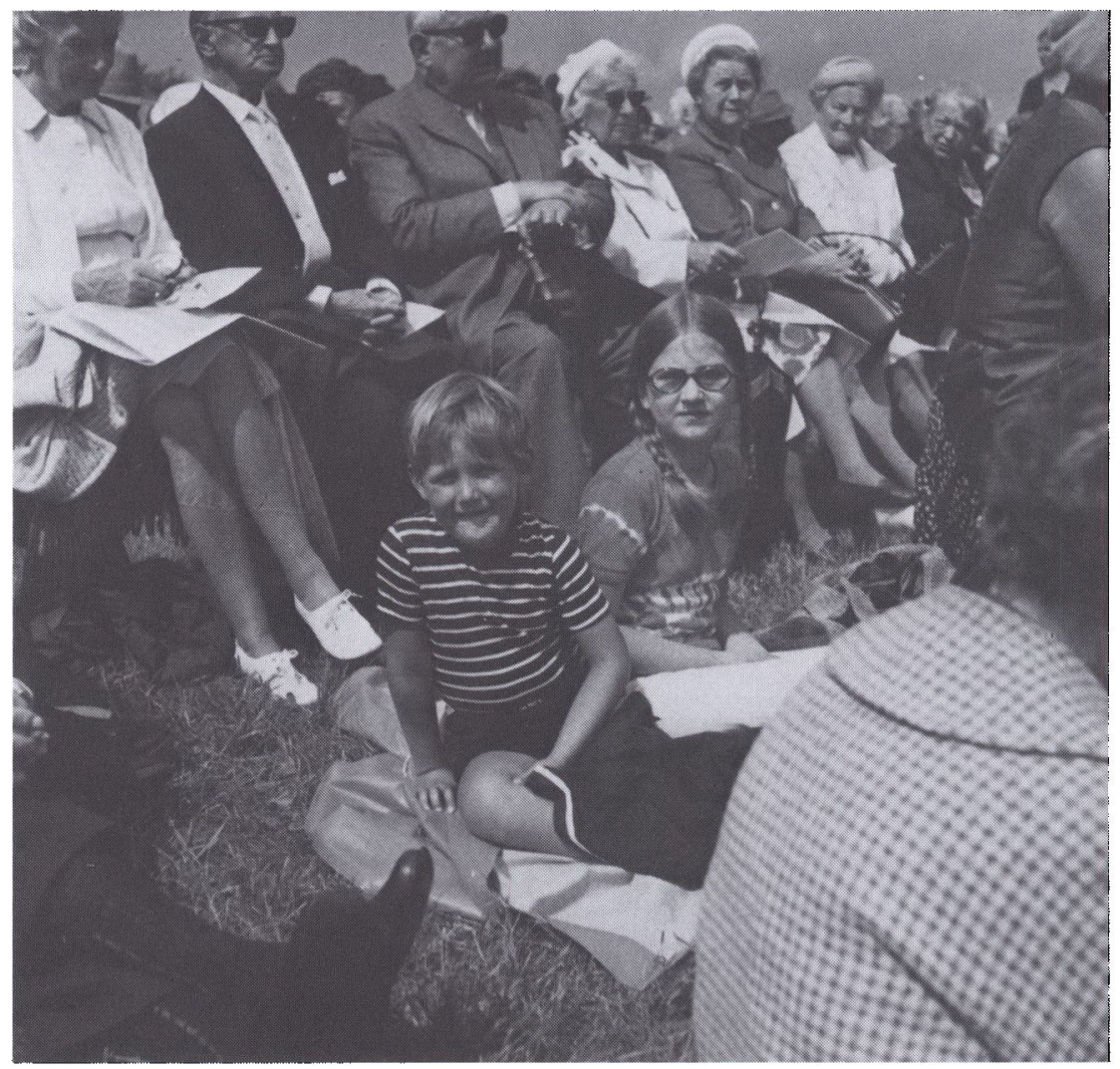

Naturligvis var de aldre i overtal ved Genforeningsfesten på Dybbal i 1970. Men der var dog også barn og unge - og måske oplevede de lidt af den hojtidsstemning, som var naturlig for genforeningsgenerationen. Foto B.Herlin-Jensen. Historiske Samlinger, Aabenraa. 
der stadig ske uendelig meget, man kan simpelthen ikke sætte historiens hjul i stå; så hvad enten vi ønsker eller ikke ønsker mere historie, så kommer den. Hvem bønnen om tid til at tæenke sig om er rettet til, står hen i det uvisse, og der er $\mathrm{i}$ historien ingen fortrydelsesret. Og hvis man prøver på at lodde dybden i det udtryk, at vi er prisgivet tidens tilstrækkelighed, så må det vel betyde, at tiden, opfyldt af de umiddelbare foruroligende menneskelige problemer, må være os nok. At være prisgivet tidens tilstrækkelighed, det er noget, vi i givet fald måtte affinde os med, men hvis det er rigtigt, så står tiden stille, og så er der intet før og intet efter, og hvis der ikke er en fremtid, er der ejheller en fortid. Peter Seeberg sagde ikke alene farvel til historien, han fornægtede den. Hvor meget tidsånden fra ungdomsoprøret har spillet ind, skal jeg lade være usagt, men gudskelov er hele betragtningen hjernespind. Man kan som individ ikke frigøre sig fra den historie, man er opvokset $\mathrm{i}$ og med. Det ville betyde tab af store menneskelige værdier; men om man end prøvede det, så ville den enkelte stadig, hvis han eller hun er et tænkende væsen, stå tilbage med et identitetsproblem. Hvem er jeg, hvor kommer jeg fra, og hvor vil jeg engagere mig i den samfundsmæssige sammenhæng? Til afklaring af disse spørgsmål yder historien helt afgørende bidrag. Man kan ikke leve et meningsfyldt menneskeliv uden at have sin historiske baggrund $i$ orden. Peter Seebergs ord gjorde unægtelig et skår $i$ glæden over festen, men den ligger allerede langt tilbage, og er vel glemt af de fleste. Ikke desto mindre var festen et højdepunkt i den formandstid, der var mig beskåret.

Det er Historisk Samfunds store betydning, at det gennem årbøgerne, månedsskriftet, skriftrækkerne og de mange møder holder fast på og videreudvikler den sønderjyske identitet. Vi har rige kilder at øse af, og vi kan heldigvis sige "for de gamle, som faldt, er der ny overalt«.

På årsmødet i Nordborg i 1971 tog jeg Peter Seebergs handske op i et foredrag med titlen: "Vort behov for historie«. Det er trykt i Sønderjysk Månedsskrift 1971. Det var en slags forsvar for historien. Men forsvaret var sådan set ikke nødvendigt. Historien har klaret sig. Krisen, der var så udtalt omkring 1970, er nogenlunde overvundet, hvad skolen angår, men der er et stort efterslæb for de børn, der blev svigtet i ungdomsoprørets kølvand. Jeg sluttede foredraget med et ønske, og med dette ønske vil jeg også slutte denne lille hilsen til årbøgernes 100-års-dag. Gid Historisk Samfund stadig vil kunne tage vel imod de mange, der gerne vil sige goddag til landsdelens historie; jeg håber, det vil leve op til både sin videnskabelige og folkelige tradition med et fastholdt kvalitetskrav til glæde for de mange, der nu og i fremtiden finder en rigdom $i$ at se deres eget og slægtens liv $i$ en stor sammenhæng.

I de 17 år, der er forløbet siden da, har Historisk Samfund i enhver henseende levet op til dette ønske. 